\title{
PENGARUH MODEL PEMBELAJARAN \\ KOOPERATIF JIGSA WBERBANTU MEDIA ANIMASI \\ TERHADAP HASILBELAJAR SISWAPADA MATERI FLUIDA STATIS KELAS XI SEMESTER II SMA N 5 MEDAN T.P. 2013/2014
}

\author{
Jonny Haratua Panggabean dan Mikha Ferina Simanjuntak \\ Jurusan Fisika FMIPA Universitas Negeri Medan \\ mikha.ferina@gmail.com
}

\begin{abstract}
ABSTRAK
Penelitian ini bertujuan untuk mengetahuipengaruh model pembelajaran kooperatif tipe Jigsaw berbantu media animasi pada hasil belajar siswa pada materi pokok Fluida statis di kelas XI semester II SMA Negeri 5 Medan. Jenis penelitian ini adalah quasi experiment dengan populasi seluruh siswa kelas XI SMA Negeri 5 Medan terdiri dari 10 kelas. Sampel penelitian diambil 2 kelas yang ditentukan dengan teknik cluster random sampling, yaitu kelas XI IPA 10 terdiri dari 27 siswa sebagai kelas eksperimen dan kelas XI IPA 9 yang terdiri dari 31 siswa sebagai kelas kontrol. Instrumen yang digunakan dalam penelitian ini adalah tes hasil belajar berbentuk pilihan berganda sebanyak 20 soal dengan lima pilihan jawaban, yang telah dinyatakan valid oleh validator, dan 2) instrumen observasi aktivitas belajar siswa. Dari hasil penelitian nilai rata-rata pretes kelas eksperimen dan kontrol masing-masing 45,14 dan 47. Setelah diberikan perlakuan pada kelas sampel diperoleh rata-rata nilai postes kelas eksperimen dan kontrol masing-masing 72,2 dan 67,00. Pada hasil pengujian hipotesis diperoleh $t_{\text {hitung }}>t_{\text {tabel }}$ yaitu $2,186>1,676$ pada taraf signifikansi $a=0,05$. Aktivitas siswa selama pembelajaran dengan model pembelajaran kooperatif tipe Jigsaw dalam kategori sedang yaitu pertemuan I ke pertemuan II $(0,38)$ dan pertemuan II ke pertemuan III $(0,37)$ Dari data yang diperoleh maka Ha diterima yang berarti ada perbedaan akibat pengaruh dari penggunaan model pembelajaran kooperatif tipe Jigsaw berbantu media animasi dalam meningkatkan hasil belajar siswa pada materi pokok Fluida Statis di Kelas XI Semester II SMA Negeri 5 Medan T.P 2013/2014.
\end{abstract}

Kata Kunci : Model Pembelajaran Kooperatif Tipe Jigsaw, Aktivitas

\section{PENDAHULUAN}

Pendidikan memiliki peranan

penting dalam berkembangnya sebuah negara. Pendidikan juga merupakan wadah bagi peserta didik untuk mengembangkan semua potensi yang dimilikinya. Kualitas dari pendidikan juga mampu menunjukkan kualitas sebuah negara.
Mutu pendidikan di Indonesia masih sangat rendah. Hal ini bisa dilihat dari data Programme for International Study Assessment (PISA) 2012. Menempatkan Indonesia sebagai salah satu negara dengan peringkat terendah dalam pencapaian mutu pendidikan. Pemeringkatan tersebut dapat dilihat dari skor yang dicapai 
pelajar usia 15 tahun dalam kemampuan membaca, matematika, dan sains. The United Nations Educational, Scientific And Cultural Organization (UNESCO) pada 2012 melaporkan, Indonesia berada di peringkat ke-64 dari 120 berdasarkan penilaian Education Development Index (EDI) atau Indeks Pembangunan Pendidikan. Total nilai EDI itu diperoleh dari rangkuman perolehan empat kategori penilaian, yaitu angka partisipasi pendidikan dasar, angka melek huruf usia 15 tahun ke atas, angka partisipasi menurut kesetaraan gender dan angka bertahan siswa hingga kelas V Sekolah Dasar (UNESCO, 2012). Sementara itu The United Nations Development Programme (UNDP) 2011 juga melaporkan Indeks Pembangunan Manusia Indonesia menurun dari peringkat 108 pada 2010 menjadi peringkat 124 pada 2012 dari 180 negara. Dan pada 2013 dilaporkan naik tiga peringkat menjadi urutan ke-121 dari 185 negara. Data ini meliputi aspek tenaga kerja, kesehatan, dan pendidikan.

Dunia pendidikan dalam ruang lingkup yang cukup kecil juga bias dilihat dari data hasil studi pendahuluanya itu dilingkungan SMA Negeri 5 Medan. Didapati bahwa untuk hasil belajar siswa dalam mata pelajaran Fisika masih bisa dikatakan rendah. Dari 38 siswa kelas X-3 menunjukkan bahwa nilai siswa untuk mata pelajaran fisika sekitar 79,5 \% dibawah nilai Kriteria Ketuntasan Minimal (KKM). Dan juga hamper semua dari siswa menganggap mata pelajaran fisika adalah mata pelajaran yang membosankan dan menyulitkan. Bahkan hamper keseluruhan data yang diperoleh menunjukkan bahwa siswa kurang mampu dalam mengerjakan soalsoal fisika yang sudah ditugaskan oleh guru. Dari angket yang sudah disebarkan, murid menyampaikan bahwa cara guru menyampaikan materi dalam proses pembelajaran adalah mencatat dan hanya mengerjakan tugas. Hal ini juga yang mengakibatkan kurangnya ketertarikan siswa pada mata pelajaran fisika.Bahkan juga dari siswa yang telah diobservasi mengatakan bahwa hanya sekitar 2 $\%$ yang mengulang pelajaran fisika di rumah dan $98 \%$ lainnya mengatakan bahwa peserta didik jarang dan hamper tidak pernah mengulang kembali pelajaran fisika di rumah. Jika dikaji secara mendalam, memang tidaklah wajar penyebab rendahnya hasil belajar dan minat peserta didik ditimpakan pada guru semata sebab banyak faktor-faktor lain yang ikut terlibat didalamnya, antara lain siswa, lingkungan, sarana dan prasarana serta masing-masing merupakan suatu system ibarat mata rantai yang menyatu dengan yang lainnya. Tentunya masing-masing mempunyai peranan dan fungsinya sendiri. Namun dari beberapa factor tersebut yang paling bertanggung jawab dalam hasil belajar dan minat siswa adalah guru. Guru memiliki tugas mengajar, maka dia harus mengajar berdasarkan kualifikasi sebagai tenaga pengajar. Sebagai tenaga pengajar, setiap guru harus memiliki kemampuan professional dalam bidang psoses belajarmengajar atau pembelajaran. Dengan kemampuan itu, guru dapat melaksanakan perannya, yakni sebagai fasilitator, sebagai pembimbing, sebagai penyedia 
lingkungan, sebagai komunikator, sebagai model yang mampu memberikan contoh, sebagai evaluator, sebagai inovator, sebagai manajer. Dari uraian diatas peneliti beranjak untuk melakukan pembelajaran dengan menggunakan model dan media yang menarik dan mampu membuat peserta didik semangat untuk mengikuti kegiatan belajar mengajar. Model pembelajaran kooperatif sendiri adalah rangkaian kegiatan belajar yang dilakukan oleh siswa dalam kelompok-kelompok tertentu untuk mencapai tujuan pembelajaran yang telah dirumuskan. Salah satu tipe dari model pembelajaran kooperatif adalah tipe Jigsaw. Model pembelajaran kooperatif tipe Jigsaw ini pertama kali dikembangkan oleh Aronson. Model pembelajaran kooperatif tipe Jigsaw didesain untuk meningkatkan tanggung jawab siswa terhadap pembelajarannya dan juga pembelajaran orang lain. Selain saling memberitahu terhadap teman sekelompoknya. Siswa tidak hanya mempelajari materi yang diberikan, tetapi peserta didik juga harus siap memberikan dan mengajarkan materi tersebut kepadaanggota lain. Dalam (Isjoni, 2009: 77), pembelajaran kooperatif tipe Jigsaw merupakan salah satu tipe pembelajaran kooperatif yang mendorong siswa aktif dan saling menguasai materi pelajaran untuk mencapai prestasi yang maksimal. Berdasarkan uraian diatas peneliti terdorong untuk melakukan penelitian dengan menggunkan Model Pembelajaran Kooperatif Tipe Jigsaw berbantu Media Animasi untuk meningkatkan hasil belajar siswa pada materi pokok Fluida
Statis di kelas XI sem II SMA N 5 Medan T.P.2013/2014.

\section{METODE PENELITIAN}

Penelitian ini adalah penelitian dengan jenis quasi eksperimen, yaitu penelitian yang dimaksudkan untuk mengetahui ada tidaknya akibat dari suatu yang dikenakan pada subyek yaitu siswa yang bertujuan untuk mengetahui perbedaan akibat pengaruh model pembelajaran kooperatif tipe Jigsaw berbantu media animasi terhadap hasil belajar fisika siswa pada materi pokok Fluidastatis. Penilitian ini melibatkan dua kelas yang diberikan perlakuan yang berbeda. Untuk mengetahui hasil belajar siswa akan dilakukan dengan memberikan tes kepada kedua kelas sebelum dan sesudah diberi perlakuan. Adapun desain penelitian untuk hasil belajar pada kelas eksperimen dan kelas kontrol akan dirancang seperti Tabel 1.

\section{Tabel 3.1 Two Group Pretes design}

\begin{tabular}{|l|l|l|l|}
\hline Sampel & $\begin{array}{l}\text { Prete } \\
\text { s }\end{array}$ & $\begin{array}{l}\text { Perla } \\
\text { kuan }\end{array}$ & Postes \\
Kelas & $\mathrm{Y}$ & $\mathrm{P}$ & $\mathrm{Y}$ \\
$\begin{array}{l}\text { Eksperimen } \\
\text { Kelas } \\
\text { Kontrol }\end{array}$ & $\mathrm{Y}$ & $\mathrm{Q}$ & $\mathrm{Y}$ \\
\hline
\end{tabular}

Keterangan :

$\mathrm{P}=$ Pembelajaran menggunakan model pembelajaran kooperatif tipe Jigsawberbantu media animasi pada materi pokok Fluida statis.

$\mathrm{Q}=$ Pembelajaranmenggunakan pembelajaran konvensional berbantu media animasi pada materi pokok Fluida statis.

$\mathrm{Y}=$ Instrumen hasil belajar.

Populasi dalam penelitian ini adalahseluruh siswa kelas XI SMA 
Negeri 5 Medan pada semester genap T.P. 2013/2104 yang berjumlah 10 kelas dan seluruh siswa kelas XI. Sampel dalam penelitian ini ditentukan dengan menggunakan teknik cluster random sampling. Dari teknik cluster random sampling dipilih dua kelas. Kelas XI IPA 10 dengan jumlah siswa 27 orang dijadikan sebagai kelas eksperimen yaitu kelas yang diberi perlakuan dengan menggunakan model pembelajaran kooperatif tipe Jigsaw berbantu media animasi dan kelas XI IPA 9 dengan jumlah siswa 31 orang dijadikan sebagai kelas kontrol yaitu kelas yang diberi perlakuan dengan menggunakan pembelajaran konvensional berbantu media animasi

Tes pada umumnya digunakan untuk menilai dan mengukur hasil belajar siswa, terutama hasil belajar kognitif berkenaan dengan penguasaaan bahan pengajaran sesuai dengan tujuan pendidikan dan pengajaran. Dalam penelitian ini tes hasil belajar merupakan tes objektif dengan bentuk pilihan berganda Jumlah seluruh spesifikasi instrumen ini adalah sebanyak 20 soal dalam bentuk pilihan berganda dengan 5 jawaban (option). Tes ini juga disusun berdasarkan Taksonomi Revisi Bloom ranah kognitif yaitu

Untuk melakukan uji-t terlebih dahulu menghitung uji normalitas dan homogenitas varians kedua kelompok sampel.

a. Uji Normalitas

Uji normalitas ini bertujuan untuk memeriksa apakah data pretes dan data postes kedua kelas sampel berdistribusi normal atau tidak, yang merupakan salah satu syarat supaya dapat menggunakan uji statistik $t$ pada pengujian hipotesis. Langkah-langkah yang dilakukan adalah sebagai berikut :

a. Pengamatan $\mathrm{X}_{1}, \mathrm{X}_{2}, \ldots, \mathrm{X}_{n}$ dijadikan angka baku $\mathrm{Z}_{1}, \mathrm{Z}_{2}, \mathrm{Z}_{n}$ dengan menggunakan rumus:

$$
\mathrm{Z}_{1}=\frac{X_{i}-\bar{X}}{S}
$$

b. Untuk bilangan baku dihitung dengan menggunakan daftar distribusi normal baku dan kemudian dihitung peluang dengan rumus: $\mathrm{F}\left(\mathrm{Z}_{i}\right)=\left(\mathrm{Z} \leq \mathrm{Z}_{i}\right)$

c.Menghitung proporsi $\mathrm{S} \quad\left(\mathrm{Z}_{i}\right)$ dengan rumus :

$$
\mathrm{S}\left(\mathrm{Z}_{\mathrm{i}}\right)=\frac{\text { Banyak } Z_{1}, Z_{2}, \ldots . . Z_{n}, \text { yang } \leq Z_{1}}{n}
$$

d. Menghitung selisih F ( $\left.Z_{\mathrm{i}}\right)$-S $\left(\mathrm{Z}_{\mathrm{i}}\right)$, kemudian menentukan harga mutlaknya.

e. Mengambil harga mutlak yang paling besar dari selisih itu disebut $\mathrm{L}_{\text {hitung. Selanjutnya pada }}$ taraf signifikan $\alpha=0,05$ dicari harga $L_{\text {tabel }}$ pada daftar nilai kritis L untuk uji Liliefors. Kriteria pengujian ini adalah apabila Lhitung $<$ Ltabel maka berdistribusi normal.

Untuk mengetahui apakah data pretes kedua kelas sampel homogen atau tidak, digunakan uji homogenitas yaitu menguji kesamaan varians, yang merupakan salah satu syarat supaya dapat menggunakan uji statistik $t$ pada pengujian hipotesis. Dalam hal ini yang diuji yaitu kesamaan varians kedua kelas sampel dengan rumus:

$$
\mathrm{F}_{\text {hitung }}=\frac{S_{1}^{2}}{S_{2}^{2}}
$$

Dengan kriteria pengujian : terima $\mathrm{H}_{\mathrm{o}}$ jika data berasal dari populasi yang homogen jika $\mathrm{F}_{\text {hitung }}<$ 
$F_{\text {tabel dimana }} F_{\text {tabel }}$ didapat dari daftar distribusi $\mathrm{F}$ dengan $\alpha=0,05$. Disini $\alpha$ adalah taraf nyata untuk pengujian.

Untukmengetahuitidak

adanyakesamaankemampuanawalsi swa pada keduakelompoksampel, makadigunakanuji t.

Untuk melihat pengaruh menggunakan model pembelajaran kooperatif tipe Jigsaw berbantu animasi terhadap hasil belajar siswa. Untuk menganalisis kemampuan akhir digunakan uji beda (uji t), setelah didapatkan ada perbedaan, maka bisa dilihat pengaruh model pembelajaran kooperatif tipe Jigsaw berbantu media animasi terhadap hasil belajar siswa.

\section{HASIL DAN PEMBAHASAN}

Pencapaian hasil belajar diidentifikasikan sebagai perubahan yang dicapai pada waktu pretes dan postes. Rata-rata nilai pretes 45,14 dan postes 72,2 . Nilai pretes dan postes siswa dapat dilihat pada Gambar1, Gambar 2, Gambar 3 dan Gambar 4.

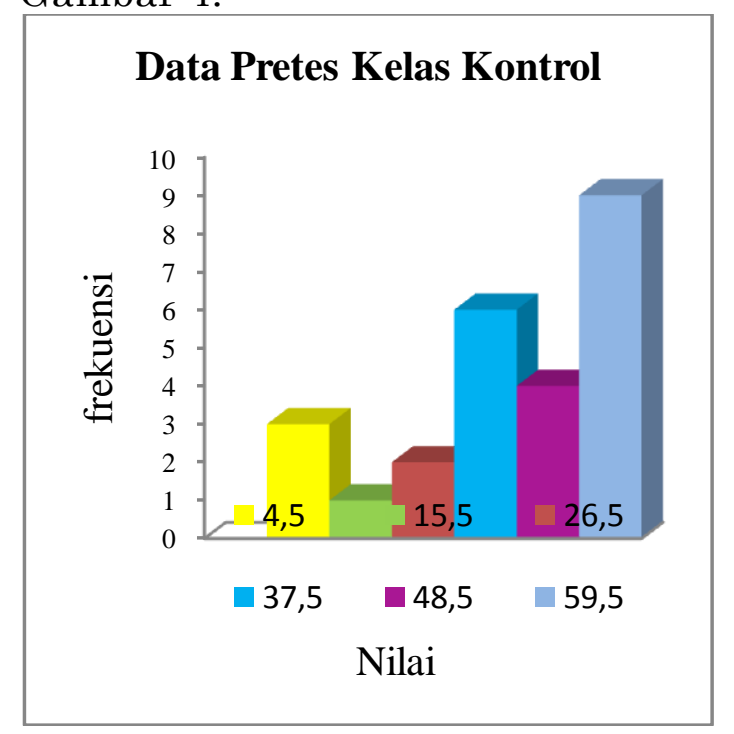

Gambar 1. Nilai pretes kelas eksperimen

\section{Data Pretes Kelas Kontrol}

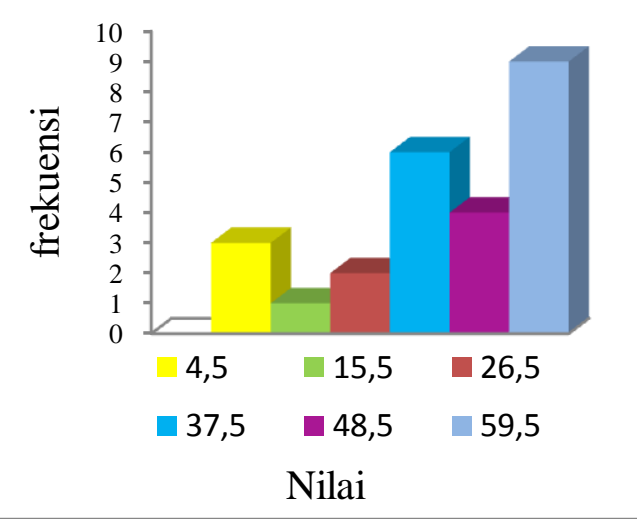

Gambar 2. Nilai pretes kelas Kontrol

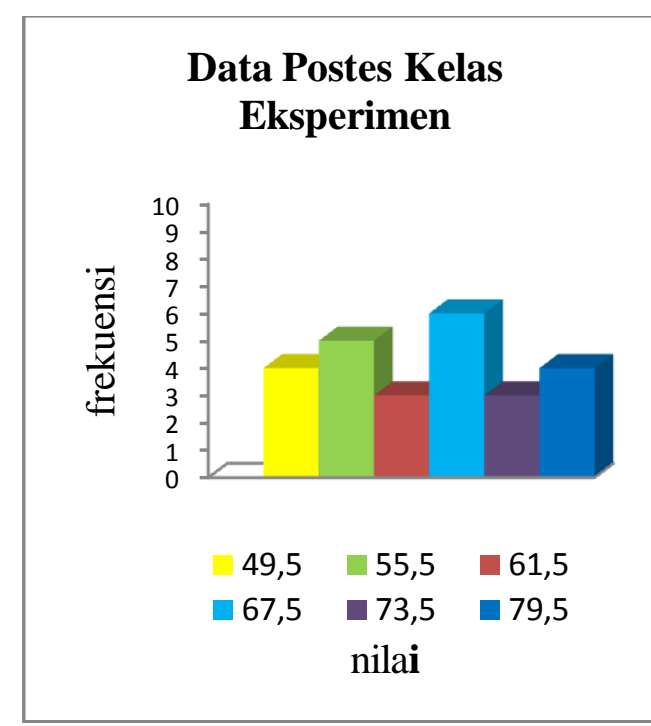

Gambar 3. Nilai postes kelas eksperimen

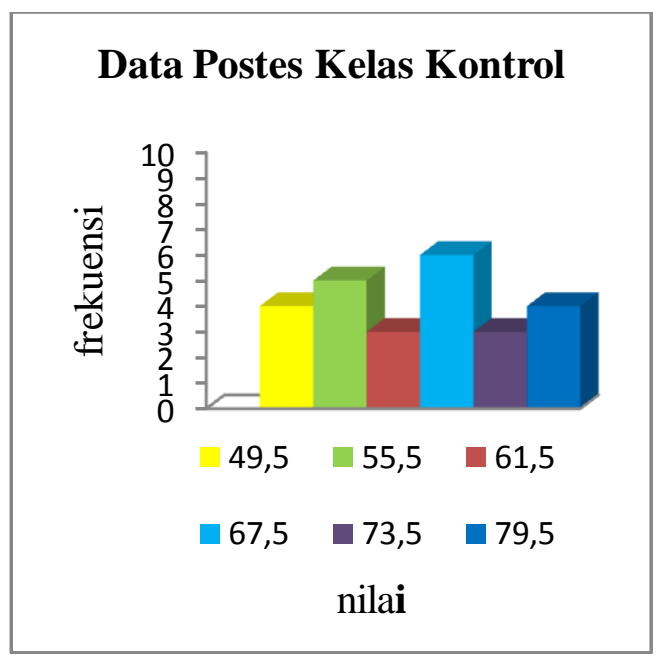

Gambar 4 Nilai postes kelas Kontrol 
Hasil

penelitian

menunjukkan, bahwa hasil belajar siswa dengan menggunakan model pembelajaran kooperatif tipe Jigsaw berbantu media animasi lebih baik dibandingkan dengan hasil belajar siswa menggunakan pembelajaran konvensional, hal ini dapat dilihat dari hasil postes kelas eksperimen memperoleh rata-rata nilai 72,2 , sedangkan hasil postes di kelas kontrol memperoleh rata-rata nilai 67. Penelitian yang dilakukan di SMA N 5 Medan menggunakan sampel dua kelas dan ditetapkan XI IPA 9 sebagai kelas kontrol dan XI IPA 10 sebagai kelas eksperimen. Sebelum di berikan perlakuan yang berbeda kepada masin-masing kelas terlebih dahulu dilakukan tes awal (pretes) untuk mengetahui kemampuan awal siswa pada materi Fluida statis. Hasil penelitian diperoleh nilai rata-rata pretes siswa di kelas eksperimen sebesar 45,4 dengan standar deviasi 151,91 dan di kelas kontrol diperoleh nilai rata-rata pretes siswa sebesar 47,6 dengan standar deviasi 177,33. Berdasarkan hasil tersebut menunjukkan bahwa kemampuan awal siswa pada kelas eksperimen dan kelas kontrol adalah sama.

Setelah diketahui memiliki kemampuan yang sama pada kelas eksperimen maupun kelas kontrol maka diberi perlakuan yang berbeda. Pada kelas ekseperimen diberi perlakuan untuk melihat perbedaan akibat pengaruh model pebelajaran kooperatif tipe Jigsaw maka di peroleh, thitung $>t_{\text {tabel }}(2,186$ $>1,676)$, dimana nilai rata-rata postes di kelas eksperimen adalah 72,2 dengan standar deviasi 8,04 dan rata-rata postes kelas kontrol adalah 67 dengan standar deviasi 8,89. Maka dapat disimpulkan bahwa ada perbedaan akibat pengaruh model pembelajaran kooperatif tipe Jigsaw berbantu animasi terhadap hasil belajar siswa pada materi pokok Fluida Statis di kelas XI Semester II SMA Negeri 5 Medan T.P. 2013/2014.

Penilaian yang dilakukan dalam penelitian ini selain hasil belajar juga dilakukan penilaian aktivitas belajar. Hal ini terlihat dari peningkatan dari pertemuan I hingga pertemuan II sebesar 0,38 atau bisa dikatakan peningkatan termasuk dalam kategori sedang, sedangkan peningkatan dari pertemuan II hingga pertemuan III sebesar 0,37 atau bisa dikatakan peningkatan termasuk dalam kategori sedang. Sehingga dapat disimpulkan bahwa pembelajaran yang diajarkan menggunakann model pembelajaran kooperatif tipe Jigsaw berbantu animasi dapat meningkatkan aktivitas belajar siswa pada materi pokok Fluida statis

Sedangkan observasi aktivitas belajar siswa selama menerapkan Pembelajaran Konvensional berbantu animasi menunjukkan bahwa mengalami peningkatan dari pertemuan I ke pertemuan II dan juga peningkatan terjadi dari peningkatan dari pertemuan II hingga pertemuan III. Hal ini bisa dilihat dari tabel diatas yaitu peningkatan dari pertemuan I hingga pertemuan II sebesar 0,19 atau bisa dikatakan peningkatan termasuk dalam kategori rendah, sedangkan peningkatan dari pertemuan II hingga pertemuan III sebesar 0,48 atau bisa dikatakan peningkatan termasuk dalam kategori sedang 


\section{KESIMPULAN DAN SARAN}

Kesimpulan penelitian ini didasarkan pada temuan-temuan dari data-data hasil penelitian, sistematika sajiannya dilakukan dengan memperhatikan tujuan penelitian yang telah dirumuskan. Adapun kesimpulan yang diperoleh antara lain:1)Hasil belajar siswa dengan model pembelajaran kooperatif tipe Jigsaw berbantu animasi terhadap hasil belajar siswa pada materi pokok Fluida statis adalah 72,2 dan belum memenuhi KKM, 2) Hasil belajar siswa dengan pembelajaran konvensional pada materi pokok materi adalah 67,00 dan belum memenuhi KKM, 3) Aktivitas belajar siswa setelah menerapkan model pembelajaran kooperatif tipe Jigsaw berbantu animasi diperoleh pertemuan I hingga pertemuan II sebesar 0,38, sedangkan peningkatan dari pertemuan II hingga pertemuan III sebesar 0,37 atau bisa dikatakan meningkat termasuk dalam kategori sedang, 4) Aktivitas belajar siswa setelah diajarkan menggunakan pembelajaran konvensional diperoleh pertemuan I hingga pertemuan II sebesar 0,19 atau, sedangkan peningkatan dari pertemuan II hingga pertemuan III sebesar 0,48 atau bisa dikatakan meningkat termasuk dalam kategori sedang, 5) Ada pengaruh akibat penggunaan model pembelajaran kooperatif tipe Jigsaw berbantu animasi terhadap hasil belajar siswa pada materi pokok Fluida Statis di kelas XI Semester II SMA N 5 Medan T.P 2013/2014.

\section{Saran}

Berdasarkan hasil penelitian dan kesimpulan diatas, maka sebagai tindak lanjut dari penelitian ini disarankan beberapa hal sebagai berikut :

Bagi pembaca diharapkan agar dapat menggunakan alokasi waktu semaksimal mungkin sehingga tiap tahap dari model pembelajaran kooperatif tipe Jigsaw berbantu animasi dilaksanakan semaksimal mungkin.Kepada pembaca yang ingin meneliti tentang model pembelajaran kooperatif tipe JigSaW berbantu animasi agar lebih mengarahkan siswa supaya lebih kondusif sehingga hasil belajarnya lebih baik.Kepada pembaca yang ingin meneliti tentang model pembelajaran kooperatif tipe JigsaW berbantu animasi supaya menambahkan jumlah observer agar lebih maksimal

\section{DAFTAR PUSTAKA}

Amelia(2013), Pengaruh Model Pembelajaran Kooperatif Tipe Jigsaw Terhadap Hasil Belajar Siswa Pada Materi Pokok Alat Optik Di Kelas VII Semester II SMP N 5 Binjai T.A 2012/2103., Skripsi,FMIPA,Unimed,Medan. Arikunto,S.,(2012), Dasar-Dasar Evaluasi Pendidikan, Penerbit Bumi Aksara,Jakarta.

Arsyad,A.,(2007), Media Pembelajaran, Penerbit PT Raja Grafido,Jakarta.

Djamarah,S B.,(2011), Psikologi Pendidikan, Penerbit Rhineka Cipta, Jakarta.

Fakultas Matematika dan Ilmu Pengetahuan Alam,(2012),

Buku Pedoman Penulisan Skripsi dan Proposal Penelitian Kependidikan, FMIPA Unimed.

Hake, R.R., 1999, Analyzing
Change/Gain Score,
$<$ http://www.google.com/\#q $=\mathrm{h}$
ake+normalized+gain\&safe $=\mathrm{O}$
$\mathrm{ff}>$


Hamalik ,O.,(2011),Kurikulum dan Pembelajara, Penerbit Bumi Aksara,Jakarta.

Isjoni.,(2009),

Pembelajaran Kooperatif Meningkatkan Kecerdasan Komunikasi antar Peserta Didik, Penerbit Pustaka Pelajar, Yogyakarta.

Meltzer, D., E., 2002, The Relationship Between Mathematics Preparation and Conceptual Learning Gains In Physics: A Possible "Hidden Variable" In Diagnostic Pretest Scores, American Journal of Physics,70: 12591268

Pakpahan,Lammindo(2013), Perbedaan Model Pembelajarn Kooperatif Tipe Jigsaw Berbantu Peta Konsep dengan Pembelajaran Konvensional Terhadap Hasil Belajar Siswa Pada Materi Pokok Bunyi Di Kelas VII Semester II SMP N 4 Pangaribuan T.A 2012/2103., Skripsi,FMIPA,Unimed,Medan. Rusman.,(2011),Model-Model

Pembelajaran

Mengembangkan

Profesionalisme

Guru,Penerbit PT Raja Grafindo Persada,Jakarta.

Sanjaya,W.,(2008), Perencanaan dan Desain Sistem Pembelajaran, Penerbit Kencana,Jakarta.

Sanajaya,Wina,(2011), Strategi Pembelajaran Berorientasi Standar Proses Pendidikan. Penerbit Kencana,Jakarta.

Sianipar,L.(2012), Perbedaan Model Pembelajarn Kooperatif Tipe Jigsaw Dengan Pembelajaran Konvensional Terhadap Hasil Belajar Siswa Pada Materi Listrik Statis Di SMP Negeri I Pematang Siantar Kelas IX
Semester I T.A 2012/2013., Skripsi,FMIPA,Unimed,Meda n.

Slameto.,(2010), Belajar dan Faktorfaktor Yang Mempengaruhinya, Penerbit Rhineka Cipta, Jakarta.

Sudjana.,(2002), Metode Statistika, Penerbit PT Tarsito,Bandung.

Sudjana,N.,2009, Penilaian Hasil Proses Belajar-Mengajar, Penerbit PT Remaja Rosdakarya,Bandung

Trianto.,(2009),Mendesain MODEL PEMBELAJARAN INOVATIF-PROGRESIF:

Konsep,Landasan dan Implementasinya pada Kurikulum Tingkat Satuan Pendidikan( KTSP),Penerbit Kencana Prenada Media Group,Jakarta. 